\title{
Folate Metabolism and Human Reproduction
}

\author{
Folatmetabolismus und menschliche Fortpflanzung
}

Author

Affiliations
C. J. Thaler ${ }^{1,2}$

${ }^{1}$ Department and Outpatient Clinic for Gynaecology and Obstetrics, Hospital of the Ludwig Maximilian University of Munich, Großhadern Campus, Hormone \& Fertility Centre Großhadern, Munich

2 Department and Outpatient Clinic for Gynaecology and Obstetrics, Hospital of the Ludwig Maximilian University of Munich, City Centre Campus, Hormone \& Fertility Centre City Centre, Munich

\section{Key words}

- assisted reproduction

- folate metabolism

- homocysteine

- human reproduction

- folliculogenesis

\section{Schlüsselwörter}

- assistierte Reproduktion

- Folatmetabolismus

- Homocystein

- menschliche Fortpflanzung

- Follikulogenese

\section{Deutschsprachige} Zusatzinformationen online abrufbar unter: www.thieme-connect.de/ ejournals/toc/gebfra

\section{received $\quad 31.7 .2014$ revised 13.8.2014 accepted 14.8.2014}

\section{Bibliography}

Dol http://dx.doi.org/ 10.1055/s-0034-1383058

Geburtsh Frauenheilk 2014; 74: 845-851 c) Georg Thieme Verlag KG Stuttgart · New York ISSN 0016-5751

\section{Correspondence}

Prof. Christian J. Thaler

Hormon- \& Kinderwunschzentrum Großhadern

Klinik und Poliklinik für Frauenheilkunde und Geburtshilfe Klinikum der Ludwig-Maximilians-Universität München Campus Großhadern

Marchioninistraße 15

81377 Munich

Thaler@med.uni-muenchen.de

\section{Abstract \\ $\nabla$}

Folate metabolism affects ovarian function, implantation, embryogenesis and the entire process of pregnancy. In addition to its well-established effect on the incidence of neural tube defects, associations have been found between reduced folic acid levels and increased homocysteine concentrations on the one hand, and recurrent spontaneous abortions and other complications of pregnancy on the other. In infertility patients undergoing IVF/ICSI treatment, a clear correlation was found between plasma folate concentrations and the incidence of dichorionic twin pregnancies. In patients supplemented with $0.4 \mathrm{mg} / \mathrm{d}$ folic acid undergoing ovarian hyperstimulation and oocyte pick-up, carriers of the MTHFR 677T mutation were found to have lower serum estradiol concentrations at ovulation and fewer oocytes could be retrieved from them. It appears that these negative effects can be compensated for in full by increasing the daily dose of folic acid to at least $0.8 \mathrm{mg}$. In carriers of the MTHFR 677TT genotype who receive appropriate supplementation, AMH concentrations were found to be significantly increased, which could indicate a compensatory mechanism. AMH concentrations in homozygous carriers of the MTHFR 677TT genotype could even be overestimated, as almost $20 \%$ fewer oocytes are retrieved from these patients per AMH unit compared to MTHFR 677CC wild-type individuals.

\section{Biochemistry of Folates and Folic Acid $\nabla$}

Folates are folic acid compounds that occur naturally in food; they are part of the vitamin B complex and are an essential nutritional component

\section{Zusammenfassung \\ $\nabla$}

Der Folatmetabolismus hat vielfältige Effekte auf ovarielle Funktion, Implantation, Embryogenese und den gesamten Verlauf der Schwangerschaft. Neben dem gut etablierten Einfluss auf die Inzidenz neuraler Fusionsdefekte finden sich Zusammenhänge zwischen verminderten Folsäure- und erhöhten Homocysteinkonzentrationen einerseits und gehäuften Spontanaborten und anderen Schwangerschaftskomplikationen andererseits. Zusätzlich zeigt sich bei Kinderwunschpatientinnen im Rahmen der IVF/ICSI-Behandlung ein deutlicher Zusammenhang zwischen Plasma-Folat-Konzentrationen und der Inzidenz dichorialer Geminischwangerschaften. Im Rahmen der ovariellen Hyperstimulation finden sich bei Trägerinnen der MTHFR-677T-Mutation unter einer Folsäure-Substitution mit täglich $0,4 \mathrm{mg}$ negative Effekte auf die Zahl gewonnener Oozyten sowie die maximale Konzentration von Östradiol am Tag der Ovulationsauslösung. Diese Effekte sind offenbar vollständig kompensierbar durch Erhöhung der täglichen Folsäuredosis auf mind. 0,8 mg. Bei entsprechend substituierten Trägerinnen des MTHFR-677TT-Genotyps finden sich die AMH-Konzentrationen signifikant erhöht, was auf einen Kompensationsmechanismus hindeuten könnte. Tatsächlich könnten die AMH-Konzentrationen homozygoter Trägerinnen des MTHFR-677TT-Genotyps allerdings überschätzt werden, denn bei ihnen konnten durchschnittlich fast 20\% weniger Oozyten pro AMH-Einheit gewonnen werden als bei Individuen mit dem MTHFR-677CC-Wildtyp-Genotyp.

of the human diet. More than 150 folate compounds are known. Folates are characterized by a pteridine and a para-aminobenzoic acid ring, with up to 8 glutamate residues attached to the carboxyl terminus ( $\bullet$ Fig. 1). Folates are therefore 


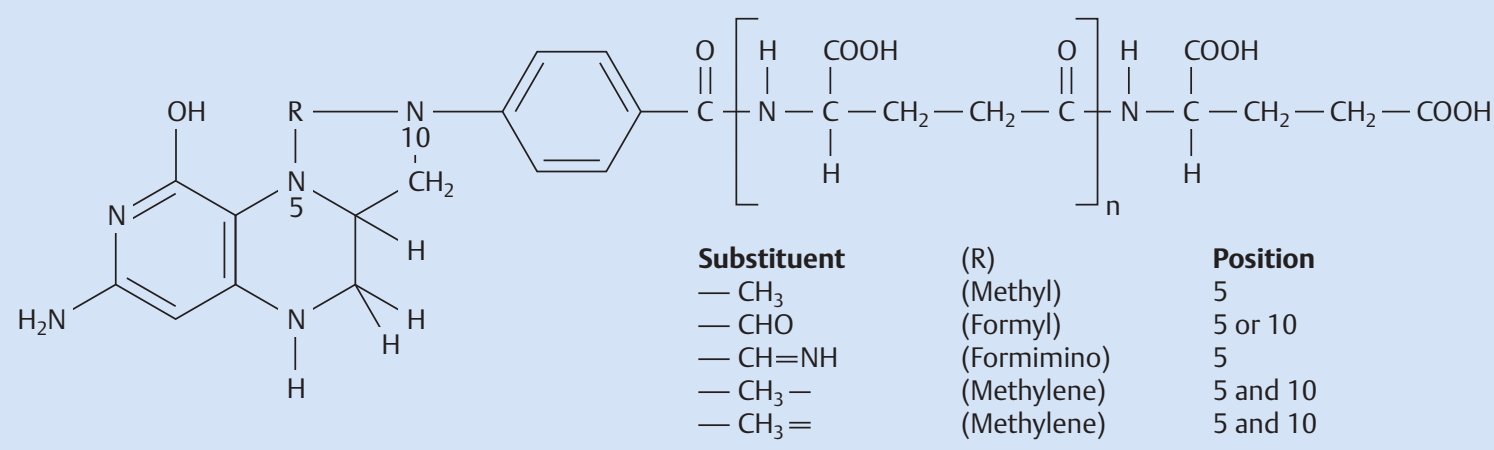

Fig. 1 Folates are characterized by a pteridine and a para-aminobenzoic acid ring, with up to 8 glutamate residues attached to the carboxyl terminus. Synthetic folic acid has a monoglutamate residue at the end of the carboxyl group; a pteroyl monoglutamate, it is the most stable form of folate. Methylene groups are bound at $\mathrm{N}$-positions 5 and 10 . The methylene group at $\mathrm{N}$-position 5 is released on donation of the methyl group (from [1]). also referred to as pteroyl polyglutamates. Folic acid is a synthetic compound with a monoglutamate residue at the end of the carboxyl group; a pteroyl monoglutamate, it is the most stable form of folate. Folic acid is commonly used in pharmaceuticals and dietary supplements [1]. All of these vitamin-active compounds, whether they are natural or synthetic, are referred to under the umbrella term "folate". As the term "folic acid" is only used for the synthetic vitamin form, references such as "folic acid requirement" and "folic acid deficiency" are no longer strictly correct [2]. Individual folate compounds demonstrate different absorption rates; folic acid is highly absorbed, whereas the availability of folates from food is limited and difficult to assess on an individual basis. The bio-availability of individual folates in food is primarily influenced by the ratio of mono- and polyglutamates [3], with a mean availability of around $50 \%$ in a mixed diet [4].

Folates (from Lat. folium: leaf) are found in green leafy vegetables and wholemeal products. Because of their high water solubility and sensitivity to heat and light, longer storage and cooking times lead to a high loss of folate activity. Overall, folate intake in the European population is insufficient, and this particularly affects people with increased folate requirements, such as women wishing to become pregnant and pregnant women. The German Nutrition Society recommends that pregnant woman and women who wish to become pregnant consume at least $0.55 \mathrm{mg}$ of a folic acid equivalent daily, which is rarely achieved without supplementary synthetic folic acid, even when adhering to a folate-rich diet [5].

\section{Metabolism of Homocysteine and Folic Acid \\ $\nabla$}

The importance of folate and of sufficient folate intake is because of its role as a precursor to 5-methyltetrahydrofolate, which acts as a methyl group donor for the re-methylation of homocysteine to methionine ( Fig. 2). Folate deficiency thus leads indirectly to elevated plasma homocysteine concentrations. Folate deficiency also results in lower concentrations of S-adenosyl methionine, an important methyl group donor required for epigenetic processes (gene methylation) and for basic processes of cell metabolism (DNA synthesis, protein synthesis).

In addition to folate intake, enzyme methylenetetrahydrofolate reductase (MTHFR) plays a crucial role in the availability of 5methyltetrahydrofolate and its methyl groups [1] ( $\bullet$ Fig. 2). This is biologically relevant in view of the numerous, relatively prevalent mutations of the MTHFR gene which significantly influence the stability and thus the functioning of the enzyme. The most common MTHFR mutation is a nucleotide exchange in position 677 of the MTHFR gene, $(\mathrm{C}<\mathrm{T})$ which involves amino acid substitution from alanine to valine in position 222 [6-8]. The resulting thermolabile MTHFR variant displays an activity loss of around $70 \%$ in homozygous $677 \mathrm{TT}$ carriers, and of $35 \%$ in heterozygous $677 \mathrm{CT}$ individuals. In the Caucasian population, around $10 \%$ of people are homozygous (677TT) and 40\% heterozygous (677CT). Only 50\% display the wild-type (677CC) mutation and thus uninhibited MTHFR activity. The MTHFR 677C $>$ T polymorphism is clinically significant because of the resulting risk of elevated homocysteine concentrations and the reduced availability of S-adenosyl methionine as a methyl group donor [9-11]. However, this can be compensated for by an increasing folic acid or 5-methyltetrahydrofolate intake $[1,6-8,11,12]$.

\section{Clinical Significance of Folate Metabolism $\nabla$}

There are numerous indicators that show that folate deficiency alone or in combination with MTHFR mutations and the resulting hyperhomocysteinaemia are associated with higher risks of complications in pregnancy, such as intrauterine growth retardation or increased rates of premature births and miscarriages $[1,12$, 13]. This is clinically significant, as patients with recurrent spontaneous abortion (RSA) show a normalisation of initially elevated homocysteine concentrations within a few weeks after starting supplementation with $0.8 \mathrm{mg} / \mathrm{d}$ folic acid [13]. The homocysteine-lowering effect is most marked in RSA patients with an MTHFR 677T mutation, as these women initially have the highest homocysteine concentrations at baseline and subsequently showed the greatest decline in concentrations following folic acid supplementation [13].

\section{Folic acid substitution and neural tube defects}

The most dramatic effect of folic acid fortification is the drop in the incidence of neural tube defects (NTD) after folic acid substitution. The importance of folate intake for human embryopathy was already suspected in the mid-1960s [14,15], and extensive empirical evidence for the preventative effect of the vitamin was subsequently collected in the 1980s and 1990s [15-22]. 


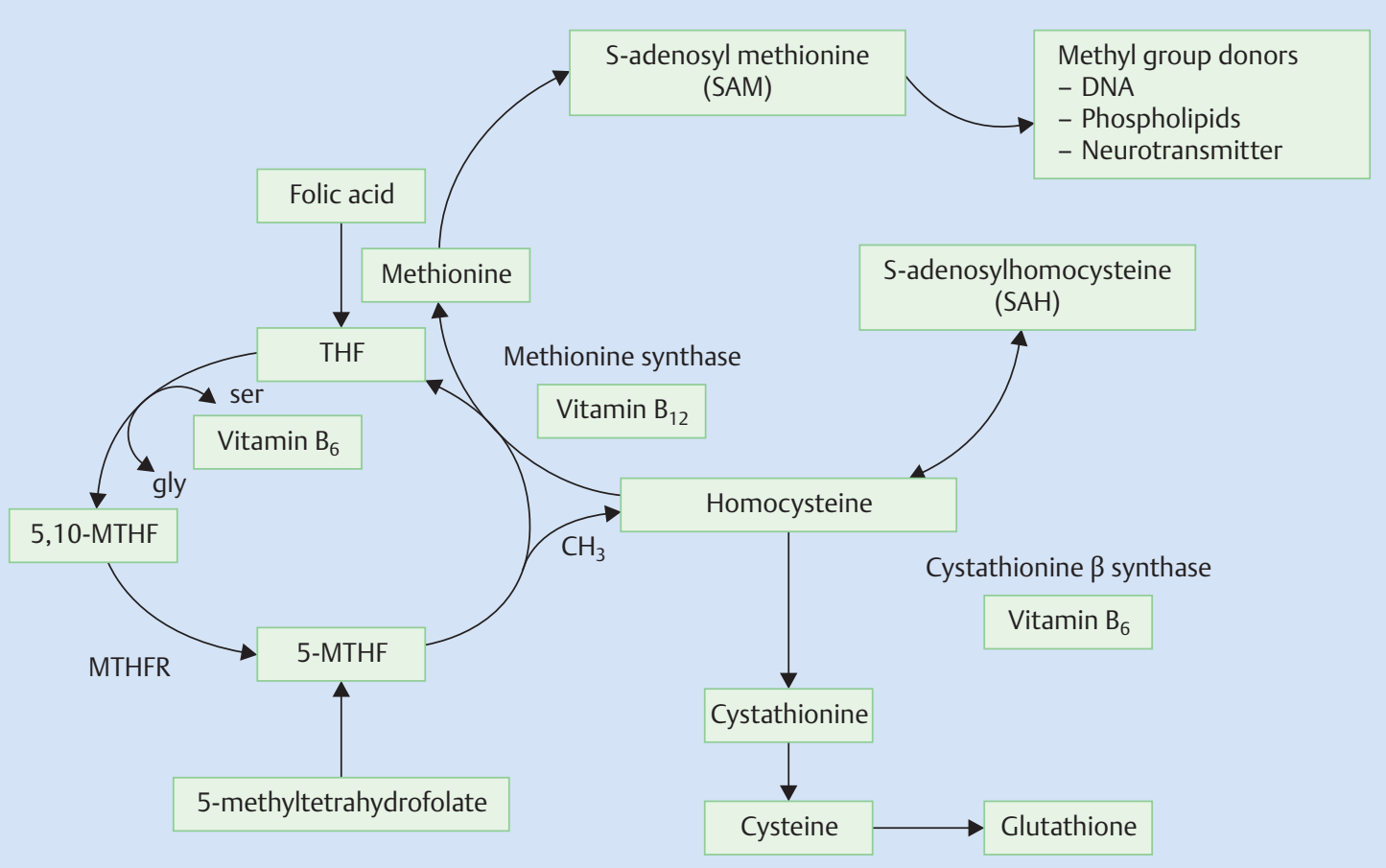

Fig. 2 Folic acid and folates are precursors to 5-methyltetrahydrofolate, which in turn acts as a methyl group donor for the re-methylation of homocysteine to methionine. Folate deficiency thus leads indirectly to elevated plasma homocysteine concentrations. Folate deficiency also results in lower

concentrations of S-adenosyl methionine, an important methyl group donor for epigenetic processes (gene methylation) and for basic processes of cell metabolism (DNA synthesis, protein synthesis).
In a meta-analysis of 8 case control studies Goh et al. were finally able to demonstrate that periconceptional supplementation with folic acid-containing multivitamin preparations (folic acid dosage $360-800 \mu \mathrm{g} / \mathrm{d}$; continued during the $1 \mathrm{st}$ trimester) reduced the NTD risk by $33 \%$ (odds ratio [OR]: 0.67; 95\% confidence interval: $0.58-0.77$ ) [23]. In their meta-analysis of three cohort studies and a prospective randomised controlled study, Blencowe et al. even found that NTD risk was reduced by $62 \%$ by folic acid supplementation prior to conception (95\% CI: 0.49-0.71) [24].

In view of this data, more than 50 countries now promote supplementation programmes to improve the folate intake. In the USA and Canada, flour and breakfast cereals are enriched with folate and, despite the relatively low concentrations (additional folic acid intake of 80 to $200 \mu \mathrm{g} / \mathrm{d}$ ), the prevalence of NTD has dropped by $19-23 \%$ [25-27] and the incidence of spina bifida was reduced by $31 \%[28]$.

\section{Folic acid fortification and anovulatory and oligoovulatory sterility}

An initially unexpected effect of folic acid substitution on ovulation and subsequent conception rates was found in a subgroup analysis done within the Nurses' Health Study [29]; the study found that the risk of anovulatory or oligoovulatory sterility was significantly reduced following regular folic acid intake, depending on the dosage, and that the incidence of anovulation-related sterility in women with the highest daily folic acid intake (topmost quintile) was reduced by $59 \%$.

\section{Folate Metabolism and Assisted Reproduction \\ $\nabla$}

The comprehensive study by Haggarty et al. carried out in the Grampian region of North-east Scotland found that folate status had far-reaching effects on aspects of assisted reproduction [30]. The study determined the regular folate and vitamin $B_{12}$ intake in detailed individual interviews with 602 women undergoing fertility treatment consisting of in vitro fertilisation (IVF) or intracytoplasmic sperm injection (ICSI). Serum folate and homocysteine concentrations were measured at the same time. Surprisingly, the analysis discovered that women with a high daily folic acid intake, high plasma folate concentrations and high plasma vitamin $B_{12}$ concentrations were significantly more likely to conceive twins. All IVF/ICSI patients were assessed following the transfer of 2 viable embryos, and, in addition to maternal age, plasma folate concentrations were found to be a major influencing factor for the rate of clinical twin pregnancies ( $\bullet$ Fig. 3) [30]. Other indications for a link between folic acid metabolism and IVF pregnancy rates were reported in a prospective study by Broxmer et al. [31]. They analysed concentrations of homocysteine, vitamin $\mathrm{B}_{12}$ (cobalamin) and folate in the blood and follicular fluids of IVF patients and investigated their effect on pregnancy rates following single embryo transfer. They found a positive correlation between plasma cobalamin concentrations and better embryo morphology as well as a significant association between high folate concentrations in follicular fluid and subsequent pregnancy rates (adjusted odds ratio 3.26; $\mathrm{p}<0.03$ ). The authors concluded that local folate/homocysteine metabolism in follicular fluid plays a significant role for embryogenesis and pregnancy rates [31]. 
Likelihood of twin birth = $\{1+\exp -[0.095( \pm 0.047) \times$ plasma folate $(\mu \mathrm{g} / \mathrm{l})$ $-0.184( \pm 0.070) \times$ age $($ years $)+3.412]\}$

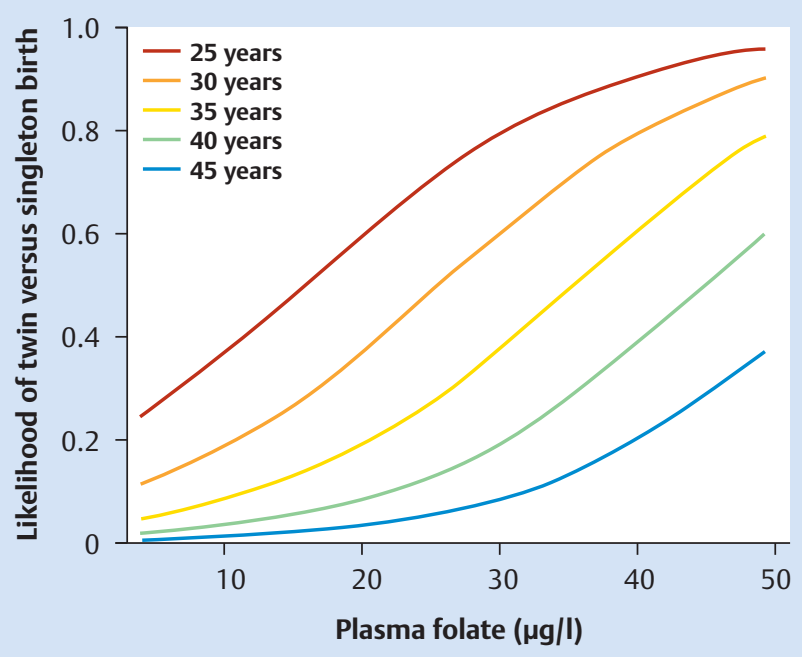

Fig. 3 Probability of twin pregnancy following IVF/ICSI and the subsequent transfer of two viable embryos (Y axis). The likelihood of having a twin pregnancy is dependent on maternal age (the younger the mother, the higher the probability). A positive correlation was found in every age group between the likelihood of twin pregnancy and plasma folate concentrations (X axis) (from [30]).
Table 1 When evaluating different ethnic populations, a negative correlation was found between MTHFR 677TT homozygosity and the incidence of spontaneously conceived dichorionic twins: a relatively high number of MTHFR 677TT homozygous individuals (20\%) are reported in Asian populations where dichorionic twins are relatively rare (6 out of 1000 ). In African populations, the incidence of spontaneously conceived dichorionic twins is relatively high at 30 per 1000 , while the incidence of MTHFR 677TT homozygosity is below detection limits. The Caucasian population holds a mid-position, with 11-13 spontaneously conceived twin births out of 1000 and a MTHFR 677TT homozygosity of around 9\% (modified from [23]).

\begin{tabular}{|c|c|c|}
\hline & $\begin{array}{l}\text { Incidence of twins } \\
(1 / 1000)\end{array}$ & $\begin{array}{l}\text { Tा homozygosity } \\
\text { (\%) }\end{array}$ \\
\hline $\begin{array}{l}\text { African populations } \\
\text { - Ghana } \\
\text { - West Africa }\end{array}$ & 32.1 & 0.0 \\
\hline $\begin{array}{l}\text { Caucasian populations } \\
\text { - Netherlands } \\
\text { - Central Europe }\end{array}$ & $11.0-13.0$ & 9.0 \\
\hline $\begin{array}{l}\text { Asian populations } \\
\text { - Hong Kong } \\
\text { - South China }\end{array}$ & 6.0 & 20.0 \\
\hline
\end{tabular}

\section{Folate Metabolism and Ovarian Function \\ $\nabla$}

\section{MTHFR $677 C>$ T polymorphism and incidence}

\section{of dichorionic twins}

Our own cohort studies show that the MTHFR 677T genotype is much less common in mothers of spontaneously conceived dichorionic twins compared to mothers with singleton births, and this difference was statistically significant [32]: While the typical genotype distribution in a Central European population was found in 159 mothers with singleton births (49\% CC; $42 \%$ CT;
$50 \%$ TT), only $23 \%$ of mothers of twins had the heterozygous and $5 \%$ of mothers of twins had the homozygous T-allele. This means that the incidence of twins born to T-allele carriers was significantly reduced $(0.43 ; 0.21-0.84 ; \mathrm{p}=0.008)$ [32]. This negative correlation between MTHFR 677T occurrence and the incidence of spontaneously conceived dichorionic twins is also found in global evaluations of different ethnic populations. A relatively high number of 677T-homozygous individuals (20\%) are reported in Asian populations, where the incidence of spontaneous twin births is known to be relatively low (6 out of 1000) compared with African regions, where the incidence of spontaneous dichorionic twins is relatively high at 30 per 1000 and where the incidence of $677 \mathrm{~T}$ homozygosity is below detection limits. The Caucasian population holds a mid-position, with 11-13 dichorionic twin births out of 1000 and a 677 TT homozygosity of around $10 \%$ (O Table $\mathbf{1}$ ) (compiled in [32]).

\section{MTHFR 677 C >T polymorphism and incidence} of dichorionic twins

In subsequent studies, we investigated the biological mechanisms behind the influence of the MTHFR $667 \mathrm{~T}$ mutation on the incidence of dichorionic twins; specifically, we investigated the effect of mutation on folliculogenesis and ovulation, fertilisation and implantation. For this, we used a model of controlled ovarian hyperstimulation and of in-vitro fertilisation. In a total of 992 oocytes, we were able to show that neither in-vitro fertilisation rates nor implantation rates differed significantly within the three different MTHFR 677CT genotypes [33]. However, during controlled ovarian hyperstimulation, we found that MTHFR 677T genotype significantly affected FSH requirement, estradiol concentrations and number of retrieved oocytes. Carriers of the $\mathrm{T}$ mutation had significantly higher total levels of active recombinant FSH $(p<0.03)$ but significantly lower maximum estradiol concentrations $(p<0.002)$ and significantly fewer retrieved oocytes $(\mathrm{p}<0.006)$. The older the patients were, the more pronounced the effect was [33]. In subsequent studies, we were able to demonstrate that primary cultures of human granulosa-lutein cells from IVF/ICSI patients with the MTHFR 677T genotype displayed significantly lower estradiol synthesis rates under standardised conditions in vitro [34]. The MTHFR effect was independent of FSH and LH receptor expression and function, as stimulation rates from recombinant FSH and $\mathrm{LH}$ were independent of MTHFR 677CT genotype ( $\odot$ Figs. 4 a to c) [34].

\section{MTHFR 677 C>T polymorphism and increased \\ folic acid substitution}

Extensive studies suggest that the increased risk for neural tube defects $[11,12,14-29]$ and spontaneous abortion [35] and the increased homocysteine concentrations associated with MTHFR 677T mutation [13] can be compensated for by increased folate substitution. Our own initial investigations into the influence of MTHFR 677T mutation on the incidence of dichorionic twin pregnancies were conducted using folic acid substitution at a dose of just $0.4 \mathrm{mg} / \mathrm{d}$, as recommended at the time [32]. Daily folic acid substitution during our studies into MTHFR 677T effects on ovarian hyperstimulation and estradiol synthesis also only consisted of $0.4 \mathrm{mg} / \mathrm{d}$ [33]. The American study by Rosen et al. then suggested for the first time that the MTHFR 677T effect on ovarian hyperstimulation could be reversed by a significantly higher folate intake, as is common in the USA (folic acid supplements in flour and cereals, higher vitamin doses in vitamin B tablets) [36]. In a follow-up study, we therefore investigated 271 IVF/ICSI 


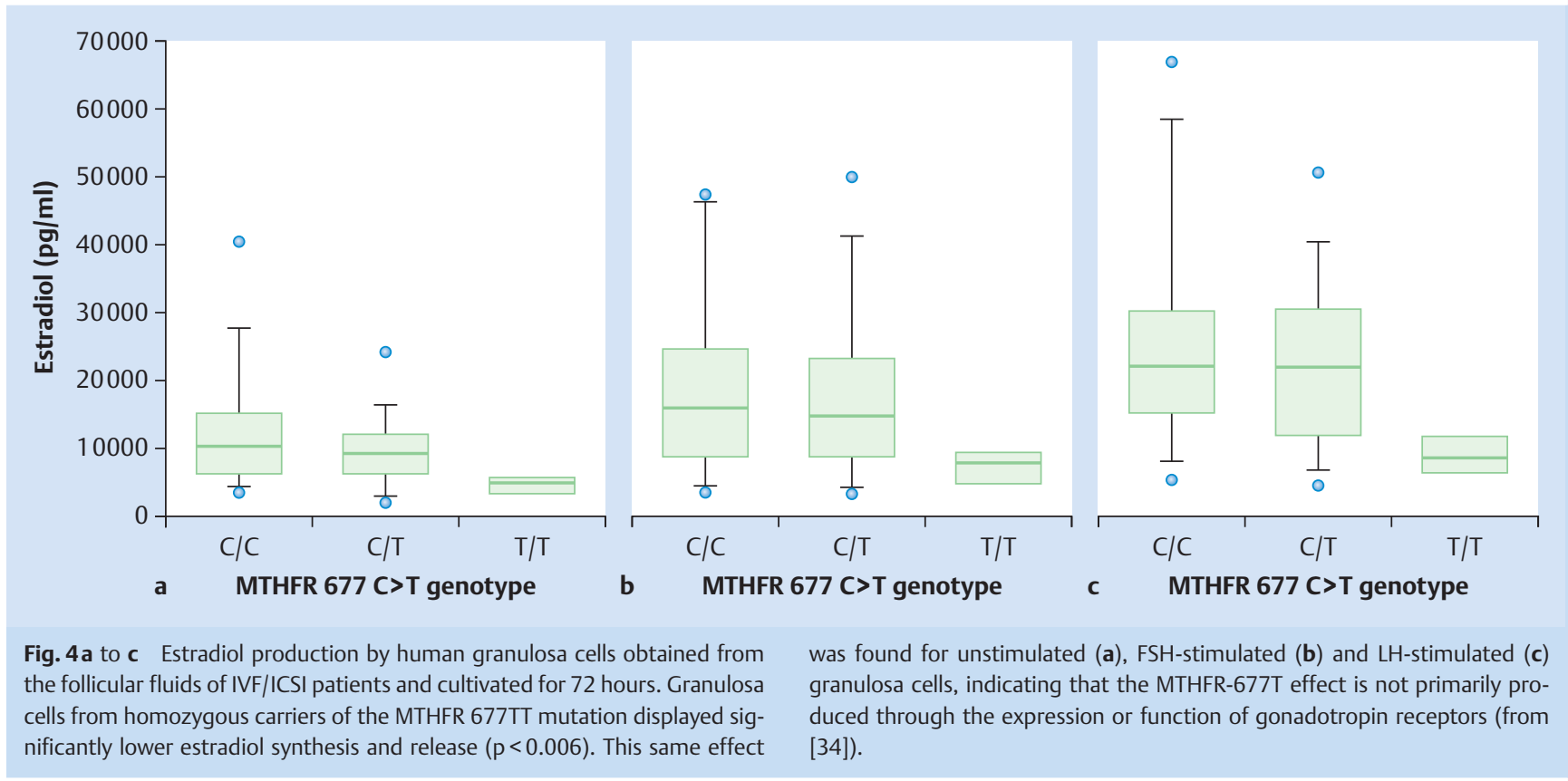

patients who were given a daily dose of at least $0.8 \mathrm{mg} / \mathrm{d}$ folic acid or $0.4 \mathrm{mg} / \mathrm{d}$ folic acid in combination with $0.4 \mathrm{mg} / \mathrm{d}$ 5-methyltetrahydrofolate. In order to verify compliance with this folic acid regime, we individually interviewed a sample consisting of 71 of these patients about the regularity and dosage of their folic acid intake; in all cases we were able to confirm that the prescribed folic acid supplementation was taken regularly and correctly (Dr. Roman Pavlik, personal statement). We found significant changes in the key data for hyperstimulation treatment with this increased folic acid dosage, compared to our initial publication which was based on an intake of $0.4 \mathrm{mg}$ folic acid/day. In contrast to the initial publication, we now found no direct MTHFR 677T effects on FSH requirement or the number of oocytes. However, multiple linear regression analysis again confirmed the negative influence of the MTFHR 677 TT genotype on the number of retrieved oocytes ( $p=0.008$ ) [37]. This initially unexpected finding could be explained by significantly increased anti-Müllerian hormone (AMH) concentrations in carriers of the MTHFR 677T genotype. Mean AMH concentrations in homozygous carriers of the MTHFR 677T genotype were highly significantly and heterozygous carriers of the MTHFR 677CT genotype were significantly $(\mathrm{p}=0.002$ and $\mathrm{p}=0.04$, respectively) higher than in MTHFR 677CC wild-type patients ( Fig. 5) [37]. The elevated AMH values in carriers of the MTHFR 677T genotype indicate an increased rate of recruited follicles, suggesting a compensatory mechanism, whereby increased folate fortification compensates for the initially reduced cyclical recruiting in carriers of the MTHFR 677T genotype. Folate substitution with at least $0.8 \mathrm{mg} / \mathrm{d}$ thus completely nullifies the negative MTHFR 677T effect on the total number of retrieved oocytes, suggesting that folate fortification would be advisable for IVF/ICSI patients. At least in carriers of the MTHFR 677T genotype, increased folic acid substitution was associated with a relative increase in AMH concentrations [37]. The significant correlation between AMH concentrations and number of oocytes described above was confirmed for all 3 MTHFR 677CT genotypes ( $p<0.001$ ), with the regression line for MTHFR 677CC wild-type patients shifted upwards by almost $20 \%$ compared with MTHFR 677TT individuals ( Fig. 6; [37]). This

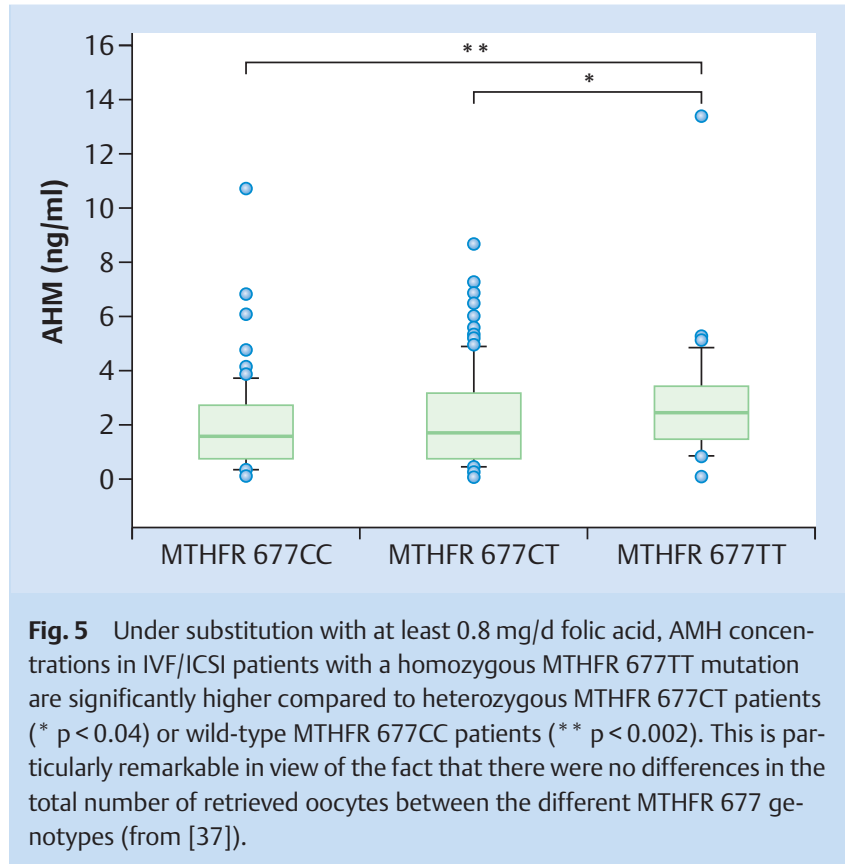

has a practical significance for clinical practice. It is important to be aware that AMH levels in 677TT patients, at least in patients receiving folate supplementation, are around $20 \%$ higher, meaning that these levels could be interpreted as "incorrectly too high". In fact, the regression lines in Fig. 6 show that oocyte numbers are approximately $20 \%$ lower at same AMH concentrations and with the stimulation regime in homozygous carriers of the MTHFR 677TT genotype. It is therefore advisable to factor in the individual MTHFR 677CT genotype and folate supplementation in the assessment of AMH concentrations. 


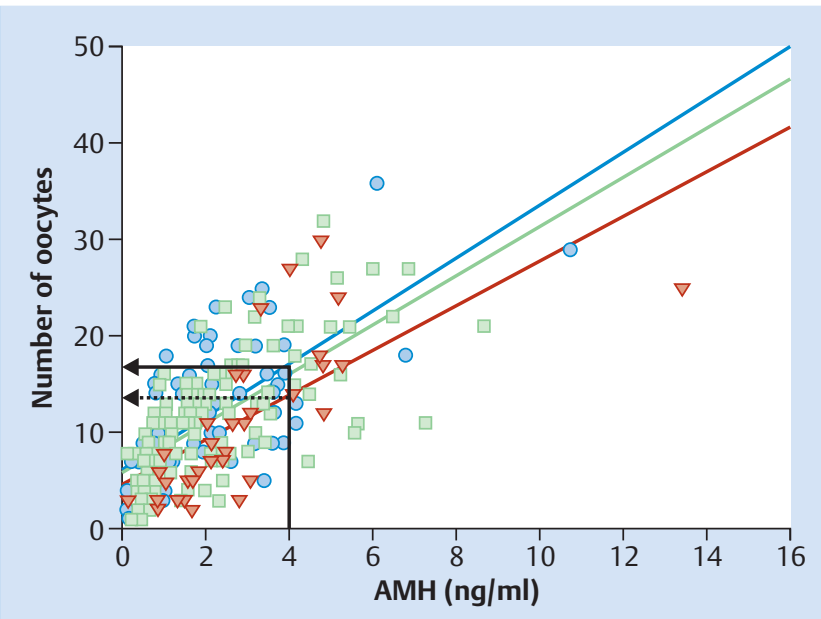

MTHFR 677CC

MTHFR 677CT

$\nabla$ MTHFR 677TT

$r=0.663, p<0.001 ; y=2.734 \times x+6.133$

$r=0.695, p<0.001 ; y=2.575 \times x+5.668$

$r=0.679, p<0.001 ; y=2.324 \times x+4.644$

Fig. 6 The significant $(p<0.001)$ correlation between AMH concentrations and number of retrieved oocytes following controlled ovarian hyperstimulation and follicular puncture is also found in individual evaluations of the three MTHFR 677 genotypes. However, the correlation line for IVF/ICSI carriers of the homozygous MTHFR 677TT mutation (red line) shifts downwards, i.e. towards lower oocyte numbers. Patients with AMH concentrations of $4 \mathrm{ng} / \mathrm{ml}$ and the MTHFR 677 TT genotype were found to have an average of 13 oocytes (arrow with broken line on the left), while carriers of the wild-type MTHFR 677CC genotype on the same stimulation regime had an average of 16 oocytes (arrow with continuous line on the left). This is clinically relevant because AMH concentrations in carriers of the homozygous MTHFR 677 TT mutation could be overestimated by around $20 \%$, at least with regard to expected oocyte numbers (modified from [37]).

\section{Conclusions}

$\nabla$

Folate metabolism affects ovarian function, implantation, embryogenesis and the entire process of pregnancy. In addition to its well-established effect on the incidence of neural tube defects, associations have been found between reduced folic acid levels and increased homocysteine concentrations on the one hand, and recurrent spontaneous abortion and other complications of pregnancy on the other. In infertility patients undergoing IVF/ ICSI treatment, a clear correlation was found between plasma folate concentrations and the incidence of dichorionic twin pregnancies. Negative effects on the number of retrieved oocytes and maximum estradiol concentrations on the day ovulation is triggered have been reported for MTHFR 677T patients under folic acid substitution of $0.4 \mathrm{mg}$ daily undergoing ovarian hyperstimulation. These effects can be compensated for in full by increasing the daily dose of folic acid to at least $0.8 \mathrm{mg}$; this daily dosage seems advisable for IVF/ICSI patients. AMH concentrations are significantly increased in carriers of the MTHFR 677TT genotype who undergo adequate substitution, which could indicate a compensatory mechanism. In fact, AMH concentrations could even be overestimated in homozygous MTHFR 677TT carriers, as almost $20 \%$ fewer oocytes are retrieved from them per AMH unit compared to carriers of the MTHFR 677CC wild-type.

\section{Acknowledgement}

$\nabla$

I would like to take this opportunity to give special thanks to Professor Friese. In recent years, he has made a major contribution to stabilising and strengthening gynaecological endocrinology and reproductive medicine in the LMU gynaecology departments with regard to staff, structures and equipment.

\section{Conflict of Interest}

$\nabla$

I have given lectures on folic acid for Merck Selbstmedikation and Aristo Pharma.

\section{References}

1 Ströhle A, Wolters $M$, Willers J et al. Mikronährstoffe in den verschiedenen Lebensphasen der Frau (Teil 3) - Schwangerschaft: Nahrung für einen optimalen Start ins Leben. Gyne 2014; 5: 33-39

2 Brönstrup A. Folat und Folsäure. Ernähr Umschau 2007; 9: 538-544

3 Ohrvik VE, Witthoft CM. Human folate bioavailability. Nutrients 2011; 3: 475-490

4 Sauberlich HE, Kretsch MJ, Skala JH et al. Folate requirement and metabolism in nonpregnant women. Am J Clin Nutr 1987; 46: 1016-1028

5 Deutsche Gesellschaft für Ernährung e.V. Referenzwerte für die Nährstoffzufuhr: Folat. Online: http://www.dge.de/pdf/ws/Referenzwerte2013-Folat.pdf; last access: 23.07.2014

6 Frosst P, Blom HJ, Milos R et al. A candidate genetic risk factor for vascular disease: a common mutation in methylenetetrahydrofolate reductase. Nat Genet 1995; 10: 111-113

7 Kang SS, Zhou J, Wong PW et al. Intermediate homocysteinemia: a thermolabile variant of methylenetetrahydrofolate reductase. Am J Hum Genet 1988; 43: 414-421

8 McAndrew PE, Brandt JT, Pearl DK et al. The incidence of the gene for thermolabile methylene tetrahydrofolate reductase in African Americans. Thromb Res 1996; 83: 195-198

9 Verhoeff BJ, Trip MD, Prins MH et al. The effect of a common methylenetetrahydrofolate reductase mutation on levels of homocysteine, folate, vitamin B12 and on the risk of premature atherosclerosis. Atherosclerosis 1998; 141: 161-166

10 Harmon DL, Woodside JV, Yarnell JW et al. The common 'thermolabile' variant of methylene tetrahydrofolate reductase is a major determinant of mild hyperhomocysteinaemia. QJM 1996; 89: 571-577

11 Jacques PF, Bostom AG, Williams RR et al. Relation between folate status, a common mutation in methylenetetrahydrofolate reductase, and plasma homocysteine concentrations. Circulation 1996; 93: 7-9

12 Ströhle A, Wolters M, Hahn A. Nährstoffsupplemente - Möglichkeiten und Grenzen. Teil 2: Ausgewählte Risikogruppen - Supplemente in der Schwangerschaft. Med Monatsschr Pharm 2013; 36: 252-266

13 Nelen WL, Blom HJ, Thomas CM et al. Methylenetetrahydrofolate reductase polymorphism affects the change in homocysteine and folate concentrations resulting from low dose folic acid supplementation in women with unexplained recurrent miscarriages. J Nutr 1998; 128: 1336-1341

14 Hibbard ED, Smithells RW. Folic acid metabolism and human embryopathy. Lancet $1965 ; 1: 1254$

15 Laurence KM, James N, Miller MH et al. Double-blind randomised controlled trial of folate treatment before conception to prevent recurrence of neural-tube defects. Br Med J (Clin Res Ed) 1981; 282: 15091511

16 Czeizel AE, Dudás I. Prevention of the first occurrence of neural-tube defects by periconceptional vitamin supplementation. N Engl J Med 1992; 327: 1832-1835

17 Czeizel $A E$. Controlled studies of multivitamin supplementation on pregnancy outcomes. Ann N Y Acad Sci 1993; 678: 266-275

18 Smithells RW, Sheppard S, Schorah CJ et al. Apparent prevention of neural tube defects by periconceptional vitamin supplementation. Arch Dis Child 1981; 56: 911-918

19 Smithells RW, Sheppard S, Schorah CJ et al. Possible prevention of neural-tube defects by periconceptional vitamin supplementation. Lancet 1980; $1: 339-340$

20 Smithells RW, Sheppard S, Wild J et al. Prevention of neural tube defect recurrences in Yorkshire: final report. Lancet 1989; 2: 498-499 
21 Smithells RW. Multivitamins for the prevention of neural tube defects. How convincing is the evidence? Drugs 1989; 38: 849-854

22 Prevention of neural tube defects: results of the Medical Research Council Vitamin Study. MRC Vitamin Study Research Group. Lancet 1991; 338: 131-137

23 Goh YI, Bollano E, Einarson TR et al. Prenatal multivitamin supplementation and rates of congenital anomalies: a meta-analysis. J Obstet Gynaecol Can 2006; 28: 680-689

24 Blencowe H, Cousens S, Modell B et al. Folic acid to reduce neonatal mortality from neural tube disorders. Int J Epidemiol 2010; 39 (Suppl. 1): i110-i121

25 Choumenkovitch SF, Selhub J, Wilson PW et al. Folic acid intake from fortification in United States exceeds predictions. J Nutr 2002; 132: 27922798

26 Quinlivan EP, Gregory JF 3rd. Effect of food fortification on folic acid intake in the United States. Am J Clin Nutr 2003; 77: 221-225

27 Dietrich M, Brown CJ, Block G. The effect of folate fortification of cerealgrain products on blood folate status, dietary folate intake, and dietary folate sources among adult non-supplement users in the United States. J Am Coll Nutr 2005; 24: 266-274

28 Williams LJ, Mai CT, Edmonds LD et al. Prevalence of spina bifida and anencephaly during the transition to mandatory folic acid fortification in the United States. Teratology 2002; 66: 33-39

29 Chavarro JE, Rich-Edwards JW, Rosner BA et al. Use of multivitamins, intake of B vitamins, and risk of ovulatory infertility. Fertil Steril 2008; 89: 668-676
30 Haggarty P, McCallum H, McBain H et al. Effect of B vitamins and genetics on success of in-vitro fertilisation: prospective cohort study. Lancet 2006; 367: 1513-1519

31 Boxmeer JC, Macklon NS, Lindemans J et al. IVF outcomes are associated with biomarkers of the homocysteine pathway in monofollicular fluid. Hum Reprod 2009; 24: 1059-1066

32 Hasbargen $U$, Lohse $P$, Thaler $C J$. The number of dichorionic twin pregnancies is reduced by the common MTHFR $677 \mathrm{C}->\mathrm{T}$ mutation. Hum Reprod 2000; 15: 2659-2662

33 Thaler CJ, Budiman H, Ruebsamen H et al. Effects of the common $677 \mathrm{C}>\mathrm{T}$ mutation of the 5,10-methylenetetrahydrofolate reductase (MTHFR) gene on ovarian responsiveness to recombinant follicle-stimulating hormone. Am J Reprod Immunol 2006; 55: 251-258

34 Hecht S, Pavlik R, Lohse P et al. Common $677 \mathrm{C}->$ T mutation of the 5,10methylenetetrahydrofolate reductase gene affects follicular estradiol synthesis. Fertil Steril 2009; 91: 56-61

35 Quéré I, Mercier E, Bellet $H$ et al. Vitamin supplementation and pregnancy outcome in women with recurrent early pregnancy loss and hyperhomocysteinemia. Fertil Steril 2001; 75: 823-825

36 Rosen MP, Shen S, McCulloch CE et al. Methylenetetrahydrofolate reductase (MTHFR) is associated with ovarian follicular activity. Fertil Steril 2007; 88: 632-638

37 Pavlik R, Hecht S, Ochsenkühn $R$ et al. Divergent effects of the $677 C>T$ mutation of the 5,10-methylenetetrahydrofolate reductase (MTHFR) gene on ovarian responsiveness and anti-Müllerian hormone concentrations. Fertil Steril 2011; 95: 2257-2262 